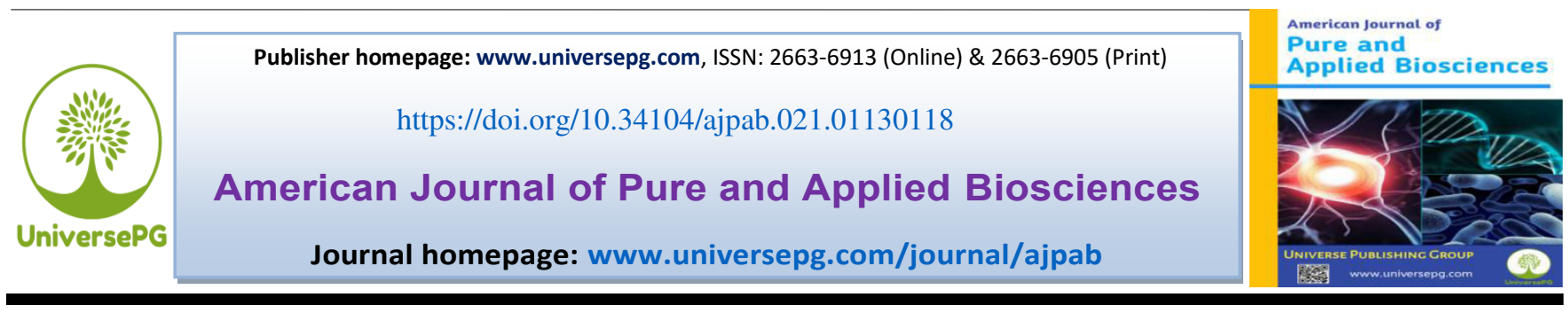

\title{
In-Vitro Antifungal Activity of Azadirachta indica, Ocimum tenuiflorum \& Murraya paniculata Leaf Extract against Three Phytopathogenic Fungi
}

\section{Meherun Nesa ${ }^{1}$, Md. Eram Hosen ${ }^{1}$, Mohammad Ashik Iqbal Khan ${ }^{2}$, Md. Humayun Kabir ${ }^{3}$ and Rashed $\operatorname{Zaman}^{1 *}$}

${ }^{1}$ Department of Genetic Engineering and Biotechnology, University of Rajshahi, Rajshahi-6205, Bangladesh; ${ }^{2}$ Plant pathology division, Bangladesh Rice Research Institute (BRRI), Gazipur-1701, Bangladesh; ${ }^{3}$ Institute of National Analytical Research and Service (INARS), Bangladesh Council of Scientific and Industrial Research (BCSIR), Dhanmondi, Dhaka1205, Bangladesh.

*Correspondence: rashedzaman@ru.ac.bd (Dr. Rashed Zaman, Associate Professor, Department of Genetic Engineering and Biotechnology, University of Rajshahi, Rajshahi-6205, Bangladesh).

\begin{abstract}
Fungal disease is one of the major problems in agriculture. Fungal pathogens are accountable for approximately $85 \%$ of plant diseases. Apart these, public health conditions are also influenced by consequential fungal infection as well as approximately 1.5 million killed and more than a billion people were affected by fungal disease. Our present exploration has been conducted to assess the antifungal efficiency of Azadirachta indica, Ocimum tenuiflorum and Murraya paniculata leaf extract against three phytopathogenic fungi viz. Pichia kudriavzevii, Lasiodiplodia theobromae and Fusarium oxysporum, at the concentration of $300 \mu \mathrm{g} / \mathrm{disc}$ by food poisoned technique. The result showed that all of these three extracts have significant antifungal efficiency against all of the tested fungus. Maximum antifungal activity was recorded in Murraya paniculata with an inhibition percentage of $100 \%(0.00 \pm 0.000 \mathrm{~mm})$ against three fungi. In addition, Lasiodiplodia theobromae and Fusarium oxysporum, growth was totally suppressed in terms of Ocimum tenuiflorum and Murraya paniculata extract. The lowest antifungal effect was $47.18 \%(34.33 \pm 0.272 \mathrm{~mm})$ revealed in Azadirachta indica extract against Pichia kudriavzevii. Among these three extracts the order of antifungal effect was Murraya paniculata $>$ Ocimum tenuiflorum $>$ Azadirachta indica. Amis of this screening to focus antifungal effects of three experimental medicinal plants. These findings indicate leaf of these three plants may be useful for the treatment of various diseases associated with these fungi and could be useful to develop novel, secure and fecund bio-fertilizer for pest control. Further phytochemicals analysis is required to evaluate the compounds responsible for their antifungal effects.
\end{abstract}

Keywords: Fungal diseases, Azadirachta indica, Ocimum tenuiflorum, and Antifungal activity.

\section{INTRODUCTION:}

Although asthma, AIDS, cancer, organ transplantation, and many other health conditions are influenced by consequential fungal infection as well as approximately 1.5 million killed and more than a billion people were affected by fungal disease yet it is a forlorn topic UniversePG I www.universepg.com by public health specialists (Bongomin et al., 2017). Apart from, the fungal pathogen is one of the biggest problems in agriculture. Fungus is the most devastating pathogen for plants and is responsible for $85 \%$ of plant's disease. 
Pichia kudriavzevii infects immunodeficient patients considered as opportunistic pathogen induce mastitis in mammals (Hurst, 2016). Additionally, Trunk fungi Lasiodiplodia theobromae is responsible for Grapevine trunk diseases (GTDs) are the most destructive diseases of vineyards worldwide (Rusin et al., 2020). Moreover, the pathogenic Fusarium oxysporum strains are liable to cause Fusarium wilt disease, conducted a major threat for agriculture, and ranked $10^{\text {th }} \mathrm{most}$ demolishing plant pathogenic fungus (Dean et al., 2012; Fisher et al., 2012).

The drugs are frequently used as antifungal have a side effect, hence there is exclusive need for the discovery of novel, secure and fecund antifungal drugs, for instance, medicinal plants could play a significant role in the field of drug discovery. Azadirachta indica extracts inhibited the growth of some fungus, bacteria, viruses, insecticides and also exposed antioxidant, antiulcer, anti-carcinogenic, and anti-malarial properties (Subapriya and Nagini, 2005). Alongside, extract from neem pledges and significantly abate fungal conidial germination (Jabeen et al., 2013). Because of these antimicrobials and pharmaethological properties, Azadirachta indica could be used for pest control along with health benefits (Rony et al., 2019). Ocimum tenuiflorum belonging to the family of Lamiaceae also known as Ocimum sanctum, Tulsi or Holy Basil. Eugenol, one of the key phytochemical of Ocimum tenuiflorum oil act against fungi leading to bio-deterioration of foodstuff during storage (Subramanian, 2014).

Murraya paniculata $L$ family of Rutaceae, commonly used as herbal therapy in India, China, Indonesia, and Bangladesh (Zhang et al., 2011). It contains an exuberant source of phyto compounds, liable for antifungal, antibacterial, analgesic, antispasmodic, bronchodilator, vasodilating actions, anti-thyperglycemic and antioxidant action(Fazal-ur-Rehman et al., 2014; P et al., 2015; Saqib et al., 2015). The above plants are widely used as medicinal plants in Bangladesh. Our present investigation deals with the evaluation antifungal efficiency of Azadirachta indica, Ocimum tenuiflorum, and Murraya paniculata leaf extract against Pichia kudriavzevii, Lasiodiplodia theobromae and Fusarium oxysporum to find out effective agents that could be useful to develop new, secure and effective bio-fertilizer to pest control and as well as UniversePG I www.universepg.com treatment of various disease associated with these fungi.

\section{MATERIALS AND METHODS:}

Plant materials - Plant leaves of Azadirachata indica, Ocimum teniflorum, and Murraya paniculata were collected from Rajshahi University Campus, Rajshahi6205 , Bangladesh. These plant leaves were used as plant material in our current study.

Extract preparation - The samples were washed individually under running tap water to remove any traces of soil particles and other dirt, cut into small pieces and air-dried for seven days. $20 \mathrm{gm}$ of powdered dried leaves soaked with $60 \mathrm{~mL}$ methanol and allowed to macerate at room temperature for 15 days with an orbital shaker. Then, strained through sterile mark in cloth and finally filtered through sterile Whatman No.1 filter paper. The filtrates were then set for 3 days to evaporate the methanol and afford a blackish mass. The output extracts were collected to glass vials and preserved separately in a refrigerator at $4^{\circ} \mathrm{C}$.

Test microorganisms - Methanol leaf extract of Azadirachta indica, Ocimum tenuiflorum, and Murraya paniculata were investigated for their antifungal efficiency against three fungi including Pichia kudriavzevii, Lasiodiplodia theobromae, and Fusarium oxysporum. Investigated fungi were collected from Prof. Joarder DNA and Chromosome Research Lab. Dept. of Genetic Engineering and Biotechnology, University of Rajshahi, Rajshahi-6205, Bangladesh.

Determination of antifungal activity - In-vitro antifungal activity was accomplished by food poisoned technique against three pathogenic fungi Pichia kudriavzevii, Lasiodiplodia theobromae and Fusarium oxysporum at the concentration of $300 \mu \mathrm{g} / \mathrm{ml} .20 \mathrm{ml}$ quantities of potato dextrose agar (PDA) media were plated in the petri dish with fungal culture. In this investigation, $300 \mu \mathrm{g} / \mathrm{ml}$ concentrations of plant extracts were spread with a sterile spreader on test organism-seeded plates. A plate containing only fungal culture was used as a control. The activity of the plant extract was determined after seven days of incubation at $37^{\circ} \mathrm{C}$ temperature. After 7 days solid dry weight of the fungus was taken using an oven. The antifungal activity of these plants extract was assessed on the 
basis of inhibition of mycelial growth (\%) and calculated using the formula (Habib et al., 2019).

Inhibition of mycelial growth $(\%)=\left[\left(\mathbf{G}_{\mathbf{c}}-\mathbf{G}_{\mathbf{t}}\right) / \mathbf{G}_{\mathbf{c}}\right] * 100$

Where, ' $\mathrm{C}$ ' is the average diameter of the fungal colony in control plates and, ' $\mathrm{T}$ ' is the average diameter of the fungal colony in poisoned plates (Gupta and Tripathi, 2011).

\section{RESULTS AND DISCUSSION:}

In-vitro antifungal efficiency of three medicinal plants Azadirachta indica, Ocimum tenuiflorum and Murraya paniculata methanol leaf extract were exhibited strong antifungal activity against Pichia kudriavzevii, Lasiodiplodia theobromae and Fusarium oxysporum at the concentration of $300 \mu \mathrm{g} / \mathrm{disc}$ (Fig 1). The diameter zone of inhibition of Azadirachta indica, Ocimum tenuiflorum and Murraya paniculata leaf extract are presented in Table 1.

Table 1: Zone of inhibition (mm) of Azadirachata indica, Ocimum teniflorum and Murraya paniulata against Pichia kudriavzevii, Lasiodpladia theobromae and Fusarium oxysporum. Values are represented by mean $\pm \mathrm{SE}$ of three biological replicates.

\begin{tabular}{|c|c|c|c|}
\hline \multicolumn{5}{|c|}{ Zone of Inhibition (mm) } \\
\hline Plant extract & Pichia kudriavzevii & Lasiodpladia theobromae & Fusarium oxysporum \\
\hline Control & $65.00 \pm 0.00$ & $44.00 \pm 0.00$ & $51.00 \pm 0.00$ \\
\hline Azadirachta indica & $34.33 \pm 0.27$ & $11.66 \pm 0.27$ & $20.00 \pm 0.47$ \\
\hline Ocimum teniflorum & $0.00 \pm 0.00$ & $0.00 \pm 0.00$ & $15.33 \pm 0.54$ \\
\hline Murraya paniulata & $0.00 \pm 0.00$ & $0.00 \pm 0.00$ & $0.00 \pm 0.00$ \\
\hline
\end{tabular}

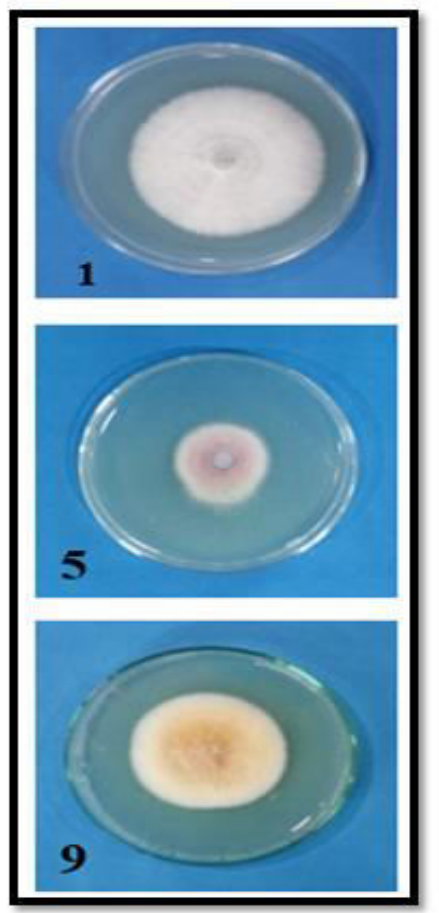

A

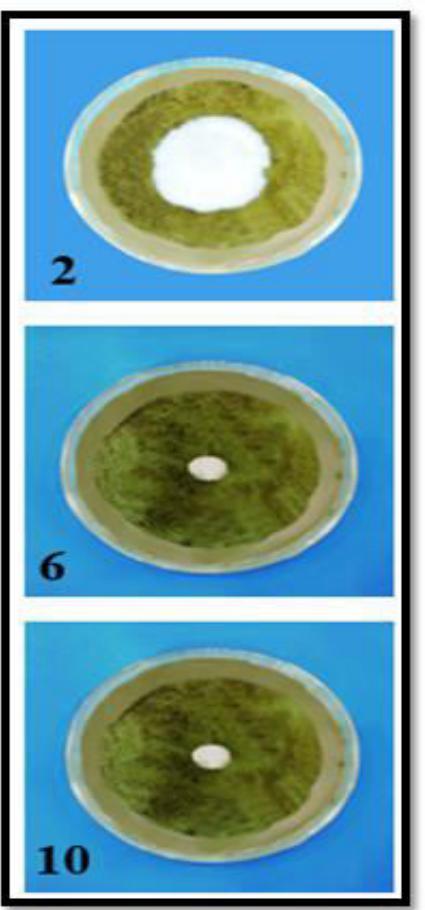

B

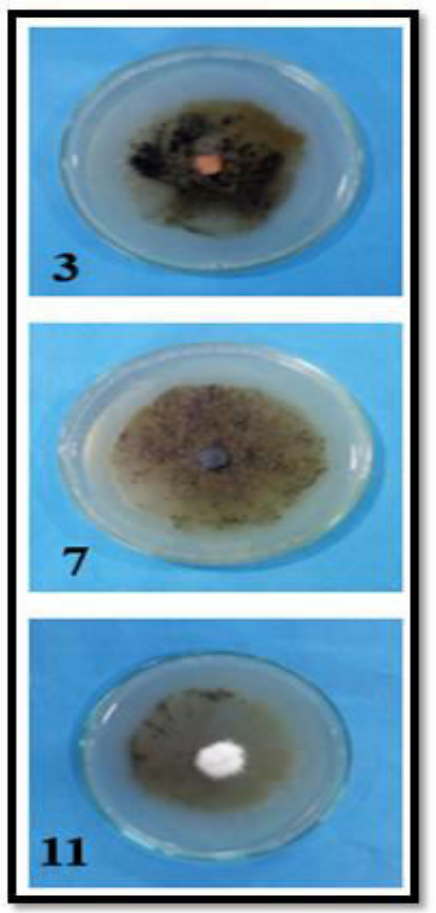

C

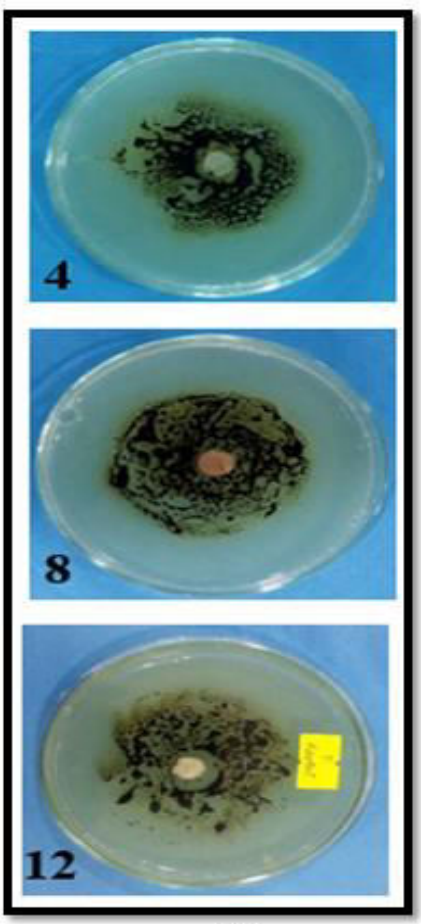

D

Fig 1: Antifungal activity of Azadirachata indica, Ocimum teniflorum and Murraya paniulata against three fungi. A) Control, B) Treated with Azadirachata indica, C) Ocimum teniflorum, D) Murraya paniulata; (1-4) Pichia kudriavzevii, (5-8) Lasiodpladia theobromae and (9-12) Fusarium oxysporum.

Among these three extracts, the most significant effect was found in Murraya paniculata leaf extract with an inhibition percentage of $100 \% \quad(0.00 \pm 0.000 \mathrm{~mm})$ UniversePG I www.universepg.com against all tested fungus (Fig 2, C). Sundaram et al. observed that all the aqueous, hexane, and ethanol extract of Murraya paniculata showed antifungal 
potency contrary to Aspergillus niger (Sundaram et al., 2011). Our present investigation found that methanol leaf extract of Azadirachta indica showed antifungal activity against all tested fungal pathogens.

In Azadirachta indica, the most significant antifungal activity was found against Lasiodiplodia theobromae and Fusarium oxysporum with inhibition percentages of $73.48 \%(11.667 \pm 0.272 \mathrm{~mm})$ and $60.78 \%(20.00 \pm$ $0.471 \mathrm{~mm}$ ) respectively (Fig $\mathbf{2}, \mathbf{A})$.

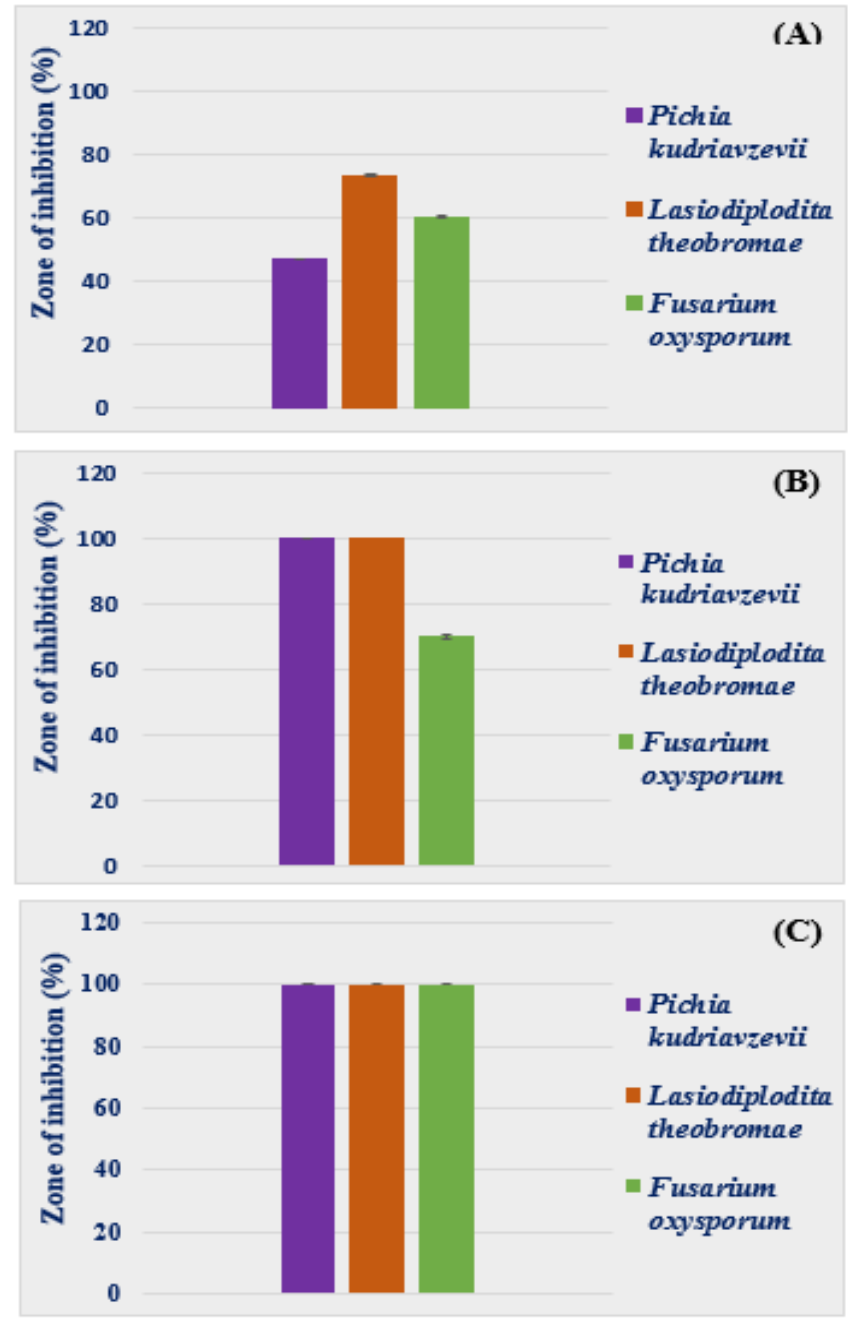

Fig 2: Inhibition percentage of Azadirachta indica (A), Ocimum teniflorum (B) and Murraya paniulata (C) methanol leaf extract against three phytopathogenic fungi Pichia kudriavzevii, Lasiodpladia theobromae and Fusarium oxysporum at the concentration of $300 \mu \mathrm{g} /$ disc. Data are represented by mean $\pm \mathrm{SE}$ of three biological replicates.

Khan et al. explained that Azadirachta indica leaf extract had a characteristic effect on dermatophytes, leading to the exclusion in protease action of dermaUniversePG I www.universepg.com tophytes due to maybe it flavonoid quercetin in the extract (Matthews, 1989). Our present finding exhibited three fungi growth was significantly inhibited by our investigated extracts at $300 \mu \mathrm{g} / \mathrm{disc}$, whereas Shivpuri et al. found Azadirachta indica ethanol extract had antifungal efficiency to five pathogenic fungi at the concentration from 500 to $1000 \mu \mathrm{g} / \mathrm{ml}$ (Shivpuri et $a l .$, 1997). In addition, Kishore et al. also reported that Azadirachta indica inhibited about 90\% Phaeoisariopsis personata conidial germination (Kishore et al., 2001).

In addition, Ocimum tenuiflorum leaf extract revealed remarkable antifungal efficiency at $300 \mu \mathrm{g} /$ disc. Among the three fungi, Pichia kudriavzevii and Lasiodiplodia theobromae growth were fully inhibited by Ocimum tenuiflorum methanol leaf extract with an inhibition percentage of $100 \%(0.00 \pm 0.00 \mathrm{~mm})$ and $100 \%(0.00 \pm 0.00 \mathrm{~mm})($ Fig 2, B).

Moreover, Ocimum tenuiflorum also showed an antifungal effect on Fusarium oxysporum with an inhibition percentage of $69.93 \%(15.33 \pm 0.544 \mathrm{~mm})$. Gupta et al. found that Ocimum Sanctum Linn aqueous extract reducing the fungal growth of A. niger, Cladpsporium sp. and Rizopous, at the concentration of $40 \%$ (Gupta et al., 2013). Besides these many scientific studies indicated that Ocimum sanctum has antifungal activity and these studies validation our present investigation (Shahen et al., 2019)

\section{CONCLUSION:}

In this investigation, Azadirachta indica, Ocimum tenuiflorum and Murraya paniculata methanol leaf extract has shown potential antifungal properties. We also found the maximum antifungal effect in Murraya paniculata against all tested fungus. These findings indicate leaf of these three plants could be useful to treat various diseases associated with these fungi. Further phytochemicals analysis is required to assess the compounds responsible for their antifungal effects.

\section{ACKNOWLEDGEMENT:}

The authors want to thank Prof. Joarder DNA \& Chromosome Research Lab, Dept. of Genetic Engineering and Biotechnology, University of Rajshahi, Rajshahi-6205, for providing financial support and other facilities during the whole research work. 


\section{CONFLICTS OF INTEREST:}

The authors declared no potential conflicts of the interest with the present experiment.

\section{REFERENCES:}

1) Bongomin F, Gago S, Oladele RO. (2017). Denning DW. Global and multi-national prevalence of fungal diseases estimate precision. J Fungi.; 3(4), 57. https://doi.org/10.3390/jof3040057

2) Dean R, Van Kan JAL, Pretorius ZA, et al. (2012). The Top 10 fungal pathogens in molecular plant pathology. Mol Plant Pathol.; 13(4), 414-430.

https://doi.org/10.1111/j.1364-3703.2011.0078 3.X

3) Fazal-ur-Rehman, Khan MF, Khan I, Shareef H, Marwat SK. (2014). Analgesic activity of carbazole alkaloid from Murraya paniculata Linn. Am J Agric Environ Sci.; 14(3), 240245.

4) Fisher MC, Henk DA, Briggs CJ, et al. (2012). Emerging fungal threats to animal, plant and ecosystem health. Nature,; $\mathbf{4 8 4}$ (7393), 186-194.

https://doi.org/10.1038/nature10947

5) Gupta SK, Tripathi SC. (2011). Fungitoxic activity of Solanum torvum against Fusarium sacchari. Plant Prot Sci.; 47(3), 83-91. https://doi.org/10.17221/56/2010-pps

6) Gupta SP, Rana KS, Sharma K, Chhabra BS. (2014). Antifungal Activity of Aqueous Leaf Extract of Ocimum Sanctum on Dominant Fungal Species of Monuments. Eur. Chem. Bull. 2(6): 609-611.

7) Habib MA, Akter S, Rahman A, Sikder J, and Hannan MA. (2019). Evaluation of neuropharmacological activities of methanolic extract of Bacopa monnieri L. in mice model. Eur. J. Med. Health Sci., 1(6), 41-49. https://doi.org/10.34104/ejmhs.01941049

8) Hurst CJ. (2016). The Rasputin Effect: When Commensals and Symbionts Become Parasitic. Adv Environ Microbiol.; 3, 289.

9) Jabeen K, Hanif S, Naz S, Iqbal S. (2013). Antifungal Activity of Azadirachta Indica Against Alternaria Solani. J Life Sci Technol.
1(1); 89-93.

https://doi.org/10.12720/jolst.1.1.89-93

10) Kishore GK, Pande S, Rao JN, Resources N, Program M. (2001). Control of Late Leaf Spot of Groundnut (Arachis hypogaea) by Extracts from Non-Host Plant Species.; 17(5), 264270.

11) Matthews GA. (1989). Natural pesticides from the neem tree and other tropical plants. Crop Prot.; 8(4), 294. https://doi.org/10.1016/0261-2194(89)90019-7

12) P. R, P. K, A. S, J. K. (2015). Coumarins and flavo-noid from Murraya paniculata (L.) Jack: Antibacterial and anti-inflammation activity. Pak J Pharm Sci.; 28(6),1947-1951. http://www.embase.com/search/results?subactio $n=$ viewrecord\&from $=$ export\&id=L607040377

13) Rony MH, Imran MAS, Mosaib MG, and Sheikh MR. (2019). Determination of antimicrobial activity of medicinal plant Cassia obtusifolia L. (Chakunda) leaf extract on selected pathogenic microbes, Am. J. Pure Appl. Sci., 1(6), 59-69. https://doi.org/10.34104/ajpab.019.01959069

14) Rusin C, Cavalcanti FR, de Lima PCG, Faria CMDR, Almança MAK, Botelho RV. (2020). Control of the fungi lasiodiplodia theobromae, the causal agent of dieback, in cv. Syrah grapevines. Acta Sci - Agron.; 43,1-9. https://doi.org/10.4025/actasciagron.v43i1.4478 $\underline{5}$

15) Saqib F, Ahmed MG, Janbaz KH, Dewanjee S, Jaafar HZE, Zia-Ul-Haq M. (2015). Validation of ethnopharmacological uses of Murraya paniculata in disorders of diarrhea, asthma and hypertension. BMC Complement Altern Med.; 15(1), 319.

https://doi.org/10.1186/s12906-015-0837-7

16) Shahen MZ, Mahmud S, Uddin ME, and Alam MS. (2019). Effect of antibiotic susceptibility and inhibitory activity for the control of growth and survival of microorganisms of extracts of Calendula officinalis. Eur. J. Med. Health Sci., 1(3), 1-9. https://doi.org/10.34104/ejmhs.0190109

17) Shivpuri A, Sharma OP, Jhamaria SL. (1997). Fungitoxic properties of plant extracts against 
pathogenic fungi. J Mycol Plant Pathol.; 27(1), 29-31.

https://www.cabi.org/isc/abstract/19981001449

18) Subapriya R, Nagini S. (2005). Medicinal properties of neem leaves: A review. Curr Med Chem - Anti-Cancer Agents.; 5(2), 149-156. https://doi.org/10.2174/1568011053174828

19) Subramanian G. (2014). Studies of Antimicrobial Properties of Different Leaf Extract of Tulsi (Ocimum tenuiflorum) against Human Pathogens.; 4(8), 149-157.

20) Sundaram M, Sivakumar, Karthikeyan et al. (2011). Studies on in vitro antibacterial, anti- fungal property and antioxidant potency of Murraya paniculata. Pakistan J Nutr.; 10(10), 925-928. https://doi.org/10.3923/pjn.2011.925.929

21) Zhang JY, Li N, Che YY, et al. (2011). Characterization of seventy polymethoxylated flavonoids (PMFs) in the leaves of Murraya paniculata by on-line high-performance liquid chromatography coupled to photodiode array detection and electrospray tandem mass spectrometry. J Pharm Biomed Anal.; 56(5), 950961. https://doi.org/10.1016/j.jpba.2011.08.019

Citation: Nesa M, Hosen ME, Khan MAI, Kabir MH, and Zaman R. (2021). In-vitro antifungal activity of Azadirachta indica, Ocimum tenuiflorum and Murraya paniculata leaf extract against three phytopathogenic fungi. Am. J. Pure Appl. Sci., 3(5), 113-118. https://doi.org/10.34104/ajpab.021.01130118 @ () 